\title{
Breast Cancer Case Control Study: Conceptual Framework and Epidemiological Study Design
}

Joedo Prihartrio*, Yoshiyuki Ohnot, Setyawati Budiningsih *, Sadao Suzuki\ Santoso Comaintt, Nakako Kubo , Didid Tjindarbumi:l:, Susumu Watanabe"§, Gunawan Tjahjadi ${ }^{1}$ I, Goi Sakamoto ${ }^{11}$, Idral Darwis:l:, Esti Soetrisno 11, Endang Sri Roostini 11

\begin{abstract}
Abstrak
Suatu penelitian kanker payudara secara Multi disipliner telah dilaksanakan di Rumah Sakit Umum Pusat Nasional Dr.Cipto Mangunkusumo Jakarta dari tahun 1988 sampai tahun 1991. Bagian studi epidemiologi dari proyek ini mempergunakan disain Case-Control dalam upaya penilaian pengaruh berbagai faktor kausal untuk kejadian kanker payudara di kalangan wanita Indonesia . Berdasarkan hasil penelitian sebelumnya maupun literatur yang ada, telah disusun suatu konsep yang spesifik bagi penelitian ini. Kerangka konsep penelitian ini menyoroti hubungan yang diperkirakan ada dalam perkembangan kanker payudara dengan faktorfaktor berikut: 1) keturunan genetik dalam keluarga, 2) pajanan hormonal, baik intrinsikmaupun ekstrinsik, 3)penumpukan lemak tubuh, 4) trauma danpajanan langsung lainnya alasjaringan payudara, 5) pola hidupyang spesifik. Penelitian ini melibatkan 300 kasus baru kankerpayudara dan 600 kontrol serasi yang dipilih daripengunjung bukan tumor di RSCM pada periode waktu yang sama. Faktor penentu keserasian kontroladalahkelompokusia dan statussosial ekonomi.
\end{abstract}

\begin{abstract}
A multi-disciplinary study on breast cancer has been conducted in theDr.CiptoMangunkusumo National Central General Hospital Jakarta from 1988 to 1991. The epidemiological component of this study used a case-control design in measuring the causal relationship of various independent variables to the risk of developing breast cancer among Indonesian women. Based on previous studies and existing literatures, a specific conceptual framework has been identified for thepurpose of this study. The conceptual framework of this study highlighted the assumed relationship of the risk in developing breast cancer with : 1) genetic traits among thefamily, 2) hormonal exposure, both indigenously and exogenously, 3) fat accumulation, 4) trauma and other direct exposure to the breast, 5) specific living pattern. The study has covered 300 newly diagnosed breast cancer cases, and 600 matched controls selected among non-breast tumor visitors of Jakarta General Hospital at the same period. The matching variables were age interval, and the socio-economic class.
\end{abstract}

Keywords: breast cancer, conceptual framework, case control study

\section{BACKGROUND}

Following the improvement of health condition among the Indonesia n people, there was a significant shift of

Department of Commu11ity Medicine, Faculty of M medicine, Univer- sity of Indonesia, Jakarta 10320, Indonesia

$t$ Department of Preventive Medicine, School of Medicine, Nagoya University, Nagoya 466, Japan

:t Department of Surgery, Faculty of Medicine, U11iversity of Indonesia, Jakarta 10430, Indonesia

$\S$ Department of Surgery, Cancer Institute, Tokyo 170, Japan

11 Department of Pathology, Faculty of Medicine, University of Indonesia, Jakarta 10430, Indonesia

f Department of Pathology, Cancer Institute, Tokyo 170, Japan

- Department of Public Health, School of Medicine, Nagoya City University, Nagoya 467, Japan

tt Research Center for Medical Science and Teech11ology, Faculty of Medicine, University of Indonesia, Jakarta 10430, Indonesia the frequency and distribution of diseases. Traditionally acute communicable diseases, such as cholerae, typhoid, bronchitis, and others played a very significant role in determining the high mortality. The National House-hold Survey in 1980 still showed this trad itional trend, but the 1986 Survey already gave evidence of this shift and chronic diseases such as cardio-vascular and malignancies were on the second and third ranks after the upper reiratory tract infection and coronary heart disease. ${ }^{1}$.

Breast cancer is the second highest of malignancy among the Indonesian women just after the cervical cancer. ${ }^{3}$ The majority of diagnosed and treated cases
in the General Hospital came rather late, and have a very low probability to be cured. ${ }^{4}{ }^{5}$ Most of them were diagnosed at the late stages, while those who were diagnosed at the early stages preferred to go to tradi- 
tional healers and at last were referred back to hospital usually at late stages.

Table 1: Ten most prevalence causes of death

\begin{tabular}{lll}
\hline RANK & 1980 & 1986 \\
\hline 1. & INFECilON & INFECilON \\
2. & MALNUTRITION & CARDIO VASCULAR \\
3. & OBSTETRICS & MALIGNANCIES \\
4. & TROPICAL DIS. & OBSTETRICS \\
5. & ACCIDENTS & ACCIDENTS \\
6. & GASTRO INTEST. & MALNUTRITION \\
7. & OTHER SYSTEMIC & TROPICAL DIS. \\
8. & CARDIO VASCULAR & GASTRO INTEST. \\
9. & MALIGNANCIES & OTHER SYSTEMIC \\
10. & HOMICIDES & HOMICIDES \\
\hline
\end{tabular}

Source : House Hold Surveys 1980 and 1986

To improve this situation, an intensive public education activities must be deployed using a multi disciplinary approach. In developing a rational plan to combat the ignorance of the community toward breast cancer, there is an acute need of clear and complete informations on the important determinant factors of breast cancer development. There are many factors which are believed to play significant role of this kind of malignancy.

A joint research project on breast cancer was established between Medical School University of Indonesia and the Japanese researchers. This project was funded by the Japanese Ministry of Education for a period of three years.7 The objectives of this study is to identify major factors which affected the development of breast cancer among the Indonesian women. Most of the studies on breast cancer lead to the multi factorial theory of this type of malignancy. To optimize the study, a clear conceptual framework has to be established as guidance for the researchers. This paper will highlight the conceptual framework and analytical methods used in this study.

\section{CONCEPTUAL FRAMEWORK}

Early in this century, the medical society has witnessed a dramatic change of medical concept on how man develops certain disease. Following the invention of microscope by Van Leuwenhoek, microbiology was established ra pidl $\mathrm{y}$ and d omina ted the modern medicine with its paradigms of specific cause of diseases. Slowly with the development of public health concept, the medical society has adopted the concept of multi causation of diseases. Interaction between specific agent with host factors and the surrounding environment is believed to be the real cause of most of the disease development. ${ }^{8} \cdot 9$

For the development of breast cancer, there are several important independent variables which are widely attributed to. These factors are as follows :

Genetic traits of malignancy

These concept will be represented by breast cancer incidence among mother-side relatives and other type of malignancies.

Hormonal exposure (internal and external)

This concept will be represented by reproductive history and the use of hormonal drugs.

External physical exposure

This concept will be represented by previous experience of strong trauma of the breast and exposure to radiation.

Fat accumulation

This concept will be represented by anthropometric measurement and the dietary pattern.

Living pattern

This concept will be represented by daily high risk living pattern such as smoking, drinking, and other risky living patterns.

The assumed interaction of these important factors can be seen in the following Figure 1that depicts the study conceptual framework.

\section{Major hypothesis}

Indonesian women with a high risk living pattern will have a significantly higher incidence rate of breast cancer, compared to those women with a low risk living pattern.

\section{Minor hypotheses}

1. Women who consumed high content of fatty food most likely will develop breast cancer.

2. Women who experienced strong breast trauma most likely will develop breast cancer.

3. Women who used hormonal drugs most likely will develop breast cancer.

4. Women who have relatives with malignant disease most likely will develop breast cancer.

5. Women who have smoking habit most likely will develop breast cancer. 
CANCER HISTORY

REPRODUCTIVE HISTORY

LACTATION

CONTRACEPTIVE

FATTY TISSUE

FATTY DIET

BREAST TRAUMA-

RADIATION

MARITAL STATUS

URBAN LIFE

LIVING PA1TERN

GENETIC TRAIT
HORMONAL LEVEL

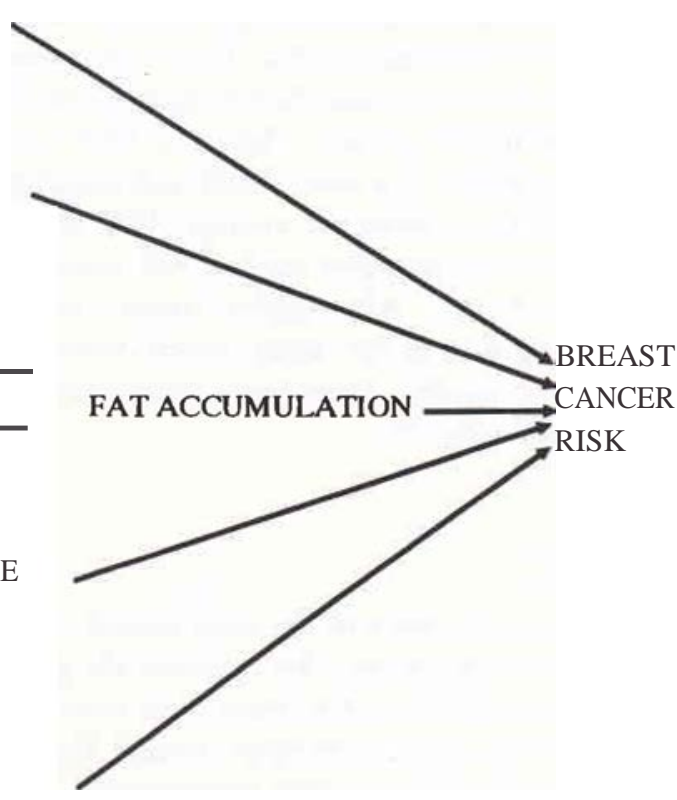

EXTERNAL EXPOSURE

SMOKING HABIT

Figure 1: Sudy conceptual framework

\section{STUDY METHOD}

Study design

Considering the ethical issues, experimental study design can not been used for this resea rch, while cohort study design will need a very long period of follow up. Based on these considerations, the research team has chosen a case control study design in testing the hy potbesis. ${ }^{10}$ Justifications to use a case control study design are as follows :

1. Breast cancer is a chronic disease which needs a very long incubation period. For this kind of disease, the case control study design will be the best choice.

2. Breast cancer is a rare disease with a low incidence rate which is suitable to be studied using a case control design.

3. Most of the assumed risk factors are widely found among the general female population in Indonesia.

4. All of the studied risk factors are women-related events which informations will be retained at an acceptable quality of memory recall for a long time.
Study population

There were two types of populations used in this case control study, namely the population of cases and controls. The cases population was defined as all newly diagnosed breast cancer cases who came to the Dr.Cipto Mangunkusumo National Central General Hospital during the study period of 1988 to 1991. Most of the breast cancer cases, especially those from middle to lower socio economic level, will be referred to this hospital, thus the derived sample can represent population of breast cancer cases in Jakarta.

The diagnostic of breast cancer case was based on the following criteria :

any positive histopathological examination on biopsies ${ }^{11}$

stage IIIA that can be diagnosed by USG/mammography

stage IIIB that can be diagnosed clinically

The control population was defined as non-breast tumor and non-malignancy patients who came for medical assistance to the surgery department of the General Hospital during the study period. The selec- 
tion of control was based on matching variables of age interval and socio economic status. For every breast cancer case there were two matched hospital controls to increase its statistical power. Using a 95\% confidence interval, statistical power of $80 \%$ and assumed relative risk of 2 times, while the average $40 \%$ of risk factor's exposure rate, the study needed 300 cases and 600 matched controls. All eligible breast cancer patients diagnosed during the study period were admitted as the case group. They were confirmed by histopathological diagnosis.

\section{Data compilation}

Demographic characteristics of the respondents were gathered through an interview. To maintain the good quality of the study information from both case and control respondents, three specially trained female paramedics were recruited for data compilation. The training for indepth interview also covering the proper technique in probing sensitive questions. Indepth interview sessions were conducted in a privacy room to guarrantee suitable environment for the respondent.

Medical characteristics were collected through physical examination, including body weight, height and hips measurements. Since the control must be free from any breast tumor, the respondents were also examined using breast palpation by the trained paramedics.

\section{Data processing and analysis}

Information from interview session and physical examination were recorded on carbonized triplicate questionnaire. One copy was sent to Japan, one copy was used for data processing, and the other copy was kept at the coordinator's office. Data processing was conducted elect ronica 11 y usi ng SPSSPC ststistica l software in a micro computer.

Data were edited and coded before electronically recorded on a magnetic diskette. Data verification was conducted using a specially designed software to check and to fix possible huma $\mathrm{n}$ error in entering the data. Data analysis was started with test of comparability of both groups. Univariate cross tabulation was conducted to identify any possible significant determinant factor in the development of breast cancer. Chi Square test was applied to check statistical significancy, while the crude Odds Ratio with its 95\% confidence interval were calculated. All possible strong determinant fac- tors were included in a Logistics Regression analysis to measure partial Odds Ratio with 95\% confidence intervals. The relative risk was estimated according for case-control study.

\section{CONCLUSIONS}

Breast cancer is a multi factorial disease which is affected by many determinant factors in its development. In studying this chronic disease, a specific conceptual framework has been established to guide the researcher in conducting the study. A case control study design with 1:2 ratio of case and control was chosen for this study. The controls were selected on matching approach based on age intervals and socio economic status. Logistics Regression analysis was applied to measure pa rtial Odds Ratio of possible determinant factors.

\section{ACKNOWLEDGMENTS}

The authors are grateful to the nurses, Ms. Ros and Ms. Emi, and public health nurses, Ms. July and Ms. Erlaini, for excellent epidemiological data collection, and to EDP staffs for helping in data processi ng. This work was supported by the Ministry of Education and Culture, Japan, Grants No. 01042007 and 04042013 ; and was partly supported by the Indonesian Cancer Foundation. This collaborative study was a part of Special Cancer Research Project in Monbusho International Scientific Research Program, with the approval of the Dean, Faculty of Medicine, University of Indonesia, No. 4383 / PT02.H4.FK / E / 88.

\section{REFERENCES}

1. Research and Development Center, M .O.H. Indon esian National House Hold Survey 1980, Jakarta, 1981.

2. Research and Devel opment Center, M .O.H. Indonesian National House Hol d Survey 1986, Jakarta, 1987.

3. Pri ha rtono J, Mangunkusu mo R. Indonesian Pathologybased Cancer Registration, Ind .Cancer Soc., Jakarta, 1990.

4. Tjindarbumi D. Management and results of operable breast cancer in several hospi tals in Jakarta: A 10-year survival ra te observation. Indon J Oncol 1991;2:147-60.

5. Sukarda IDG. Early detection of breast cancer in East Java, i mpact of public education on cancer: A longitudinal study. (Dissertation). Surabaya: Facul ty of Medicine, Airlangga University, 1984.

6. Surgery Dept. RSCM . Annual Report on Hospital ized Cancer Patients, Ja karta, 1986.

7. N, Triaspolitica. "Kanker Payudara: Informasi, Penyebab, Gejala, Stadium Dan Pengobatan." Mau Nanya Dong Dok. N.p, 28 June 2017. Web. 30 June 2017. <https:// nanyadongdok.blogspot.com/2017/06/kanker-payudarainformasi-penyebab.html>. 
8. Mausner JS, Bahn AK. Epidemiology An Introductory Text. Philadelphia: W.B. Saunders Co., 1974.

9. Lilienfeld MA, Lilienfeld DE. Foundation of Epidemiology, New York: Oxford Univ Press Inc. 1980.
10. Schlessel man JJ. Case Control Studies, New York Oxford Univ Press Inc. 1982.

11. World Health Organization. International Classification of Diseases, 10hㅡㄴ Revision, Geneve, 1990. 